\title{
Configurações
}

Revista Ciências Sociais

26 | 2020

Economy and Society: politics, practices, agents, and institutions

\section{Economy and Ecology in the Iberian Cork Oak Forests: Land Use in the Second Half of the 19th Century}

Economia e ecologia no montado ibérico de sobro: uso do solo na segunda metade do século XIX

Économie et écologie dans les forêts ibériques de chêne-liège: l'utilisation des terres dans la seconde moitié du XIXe siècle

Carlos Manuel Faísca

\section{OpenEdition}

Journals

Edição electrónica

URL: http://journals.openedition.org/configuracoes/10121

DOI: 10.4000/configuracoes. 10121

ISSN: 2182-7419

\section{Editora}

Centro de Investigação em Ciências Sociais

Edição impressa

Paginação: 83-105

ISSN: 1646-5075

Refêrencia eletrónica

Carlos Manuel Faísca, «Economy and Ecology in the Iberian Cork Oak Forests: Land Use in the Second Half of the 19th Century », Configurações [Online], 26| 2020, posto online no dia 15 dezembro 2020, consultado o 18 dezembro 2020. URL : http://journals.openedition.org/configuracoes/10121 DOI : https://doi.org/10.4000/configuracoes.10121 
Faísca, Carlos Manuel - Economy and Ecology in the Iberian Cork Oak Forests: Land Use in the Second Half of the 19th Century. Configurações, vol. 26, 2020, pp. 83-105.

\title{
Economy and Ecology in the Iberian Cork Oak Forests: Land Use in the Second Half of the $19^{\text {th }}$ Century
}

CARLOS MANUEL FAÍSCA*

CEIS20 - Universidade de Coimbra

\begin{abstract}
The supply of raw material is probably the most important issue in the cork business, mainly due to its preponderance in the industry cost structure. This article analyses, from a comparative perspective between Spain and Portugal, a practice with a high repercussion in the cork production, the use of the soil. The main goal is to identify, in the late $19^{\text {th }}$ century, agroforestry practices that reduced the cork potential of any of the countries, helping recognise a factor that can explain the gap in the level of development of the cork sector in Spain and Portugal. However, it is concluded that there were constant harmful actions against cork development in both countries. Soil mobilisation and extraction of plants, often due to cereal cultivation, led to a decline in soil fertility with a negative economic and ecological impact.
\end{abstract}

Keywords: Cork oak forest, cork, cork business, soil degradation.

\section{Resumo}

Economia e ecologia no montado ibérico de sobro: uso do solo na segunda metade do século XIX

A oferta de matéria-prima é provavelmente o aspeto mais importante no negócio corticeiro, devido à preponderância que apresenta na estrutura de custos da indústria. Neste artigo analisa-se, numa perspetiva comparada entre Espanha e Portugal, uma prática cultural com elevada repercussão na produção florestal de cortiça, o uso do solo. O objetivo principal é identificar, durante a segunda metade do século XIX, práticas agroflorestais que possam ter reduzido o potencial suberícola dos países ibéricos, ajudando a explicar o

*E-mail: carlos.faisca@uc.pt 
diferente nível de desenvolvimento do negócio corticeiro em Portugal e Espanha. Contudo, conclui-se que em ambos os países ocorreram ações nocivas para o correto crescimento da cortiça. A mobilização do solo e a extração de plantas, em virtude da cerealicultura, provocaram uma queda na fertilidade do solo e na utilidade da terra com repercussões económicas e ecológicas negativas.

Palavras-chave: montado de sobro, cortiça, negócio corticeiro, degradação do solo.

Résumé

Économie et écologie dans les forêts ibériques de chêne-liège: l'utilisation des terres dans la seconde moitié du XIX ${ }^{e}$ siècle

L'approvisionnement en matières premières est probablement l'aspect le plus important dans le secteur du liège en raison de sa prépondérance dans la structure des coûts de l'industrie. Cet article analyse, dans une perspective comparative entre l'Espagne et le Portugal, l'utilisation du sol, une pratique culturelle à forte répercussion sur la production forestière du liège. L'objectif principal est d'identifier, au cours de la seconde moitié du XIXe siècle, les pratiques agroforestières qui peuvent avoir réduit le potentiel du liège des pays ibériques, contribuant ainsi à expliquer les niveaux différents de développement du commerce du liège au Portugal et en Espagne. Nous avons cependant conclu qu'il y a eu dans les deux pays des actions néfastes pour la croissance correcte du liège. La mobilisation du sol et le déboisement, dus à la culture céréalière, ont provoqué la baisse de la fertilité du sol et de l'utilité de la terre avec des répercussions économiques et écologiques négatives.

Mots-clés: forêt de chêne-liège, liège, commerce du liège, dégradation du sol.

\section{Introduction'}

Currently, Portugal leads worldwide in all facets of the cork business, from the forestry market through industrial transformation to the commercialization of cork products. The Portuguese cork sector concentrates around two-thirds of world exports in an amount that reached, in 2018, 1,068 million euros (Associação Portuguesa de Cortiça, 2020a: 2). However, in the 19th century, the cork business, and in particular the industrial transformation and subsequent commercialization, was dominated by Spain, with several non-cork producing countries with a meaningful participation in the cork business - the United Kingdom, the United States of America and Germany, among others (Parejo Moruno, 2010: 20-23). Knowing that Portugal is, for edaphoclimatic reasons, the globe's region where the cork oak reaches its ecological optimum (Natividade, 1950: 53), the apparent underutilization of the Portuguese cork business, especially by comparison with 
the Spanish one, was the subject of several debates (Nunes, 1905; Cabreira, 1914). The goals included the identification of the reasons leading to this situation and, consequently, its adjustment. Within a relatively wide range of motives that included, for example, the customs policy or the technological "backwardness" of the Portuguese industry, the eventual lower quality of cork due to the occurrence of harmful cultural practices was also mentioned².

This article focuses on the cultural practices in the cork oak forests - Dehesa Alcornocal in Spanish and Montado de Sobro in Portuguese. While previous research focused on how the cork stripping was carried out (Faísca, 2015), the present work will address the use of soil in the lberian cork oak forests. This aspect has a strong influence on the quantity and quality of cork, as well as in the maintenance of the fertility of the land and, consequently, of its ability to develop plants, fix economic activity and populations. Based on the identification of agricultural practices in cork oak forests that are harmful to the correct development of the cork oak tree, this article proposes to achieve one main objective and a subsequent one, from a comparative perspective between Spain and Portugal. First, from an economic perspective, the main focus of this study is to understand if there were, in the second half of the $19^{\text {th }}$ century, agricultural practices in the cork oak forests of Spain and Portugal that can help to identify the reasons that led to the production of less and worse quality raw cork in any of the countries. Then, from an environmental perspective, we aim to establish whether there were human actions over nature with serious ecological effects in the medium and long term. The consequences would be the impoverishment of soils, the breakdown of the land's utility, and therefore human and environmental desertification in these regions. To reach these goals, we used several sources from the second half of the 19th century, including some official reports written by agronomists and memories of local farmers that were complemented by contemporary bibliography.

This article is organized as follows. First, we explain the impact of soil management on the economy and ecology of cork oak forests. We further clarify the main characteristics of the 19th-century cork business and how, in this historical context, the decrease in the quality of cork and the productive potential of each cork oak was a significant factor in the loss of international competitiveness. After a demonstration of the sources and methods used, we present and analyse the results of the research, as well as the institutional and political framework that probably contributed to them. Finally, we conclude that between the main cork oak forest regions of Spain and Portugal, there were no significant differences in the uses of the cork oak forest soils, subsisting soil mobilizations, and other actions with harmful effects in the production of cork, that led to the degradation of soil fertility. Likewise, and not surprisingly, the Iberian states' institutional and political 
frameworks were similar. Thus, not only the knowledge about cork oak systems was scarce in scientific research and in forestry education, but also forestry policy was oriented towards other types of issues. Besides, an agricultural policy favoured cereal crops with which the cork oak competed for all kinds of resources - environmental, financial, and so forth.

\section{Importance of the soil in the quantity and quality of the cork and its impact in the context of the $19^{\text {th }}$-century cork business}

There are essentially two types of cork oak forests globally: either areas with high tree density or areas occupied by a sparsely populated tree area with wide interspersed spaces (ca. 80 trees/hectare), resembling an African Savannah. The first ones, called Sobreirais in Portuguese and Alcornocales in Spanish, are less frequent and practically restricted, in the Iberian Peninsula, to the Province of Gerona in Catalonia. The second ones, called Montados de Sobro in Portuguese and Dehesas Alcornocales in Spanish, are more common and concentrated in the Southwest of the Iberian Peninsula, specifically in the regions of Extremadura and Andalusia in Spain, and of Alentejo and Algarve in Portugal. They are an agro-silvo-pastoral ecosystem, meaning that, together with the forest exploitation wood, acorns and cork -, this system supports livestock activities, such as grazing sheep and pigs, and agricultural activities, as the cultivation of cereals or legumes. However, cereal cultivation often creates ecological stress due to the exhaustion of soil fertility and it contributes to the weakening of the cork oak trees through the damage of their roots due to the mobilization of the soil that cultivation implies.

In Portugal, the awareness of this situation has led to the fact that the current legislation does not allow crops that affect the root system of cork oak trees done by mechanical or other means. It is even forbidden to engage in any mechanical mobilization of the soil on slopes greater than 30 per cent, as well as all those that are not carried out according to contour lines on slopes between 10 to 30 per cent (Goes and Tenreiro, 2001: 24-25). Also, symptomatic of the frequent incompatibility of these two activities - cork oak forestry and cereal farming - is that currently only 5 per cent of the area of cork oak forests of the planet is cultivated with cereals, such as wheat, barley, or oat (Associação Portuguesa de Cortiça, 2020b).

It was only in the mid-20 ${ }^{\text {th }}$ century that the Junta Nacional de Cortiça ${ }^{3}$, mainly due to the research carried out by Joaquim Vieira Natividade at the Estação Experimental do Sobreiro e do Eucalipto ${ }^{4}$, warned about the decline in the quality of Portuguese cork, as well as in quantity produced per tree. This situation

3 Junta Nacional da Cortiça was a corporate organization with several functions, one of them being the development of scientific research of the cork oak tree to improve the cork production quality and quantity in Portugal. It was created in 1936 and extinct in 1972.

4 Estação Experimental do Sobreiro e do Eucalipto was a state-owned scientific laboratory to improve both the cork oak and eucalyptus' economic possibilities. 
was, among other issues, because of the loss of soil fertility and the mutilations of the root system of the cork oaks, both with origins in the agriculture practices and cereal cultures (Natividade, 1951: 6).

Figure 1: Cork oak forest of Montado type in Southern Portugal, April 2020

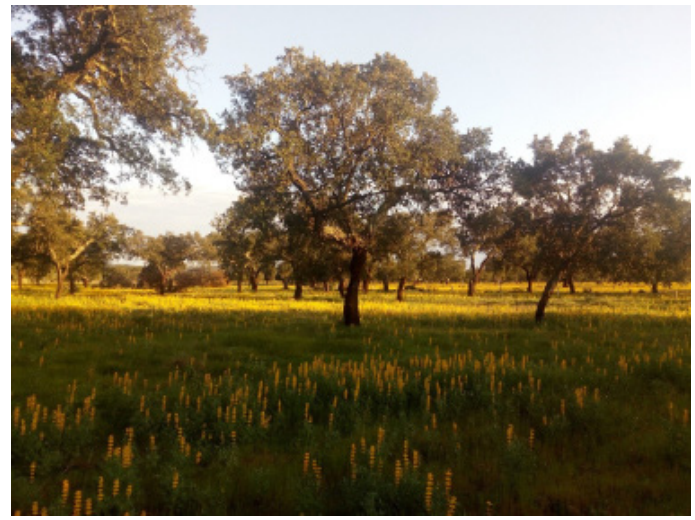

Source: Personal collection.

On several occasions, Joaquim Vieira Natividade presented a critical view of the treatment that Portuguese cork oak forests had been undergoing since the 19th century (Natividade, 1950, 1951). The most pronounced aspect was the soil, as the conservation of soil fertility was one of the most relevant problems of the Portuguese cork oak forests (Natividade, 1950: 124). Vieira Natividade stated that the cork oak forest soils suffered from several activities that led to a decline in the organic matter content present in the soil, promoting erosive work, weakening microbial activity, and making aridity more pronounced. The final consequence was the lack of strength of the cork oak trees that led to a reduction in the cork production quantity and quality (Natividade, 1950: 125). As shown in Chart 1, the cultivation of cereals led to a loss in the average calibre of cork between 30 to 50 per cent (Natividade, 1951: 13), compared with an area without any agriculture practices. 
Chart 1: Cork growth in the tree according to the use of the soil

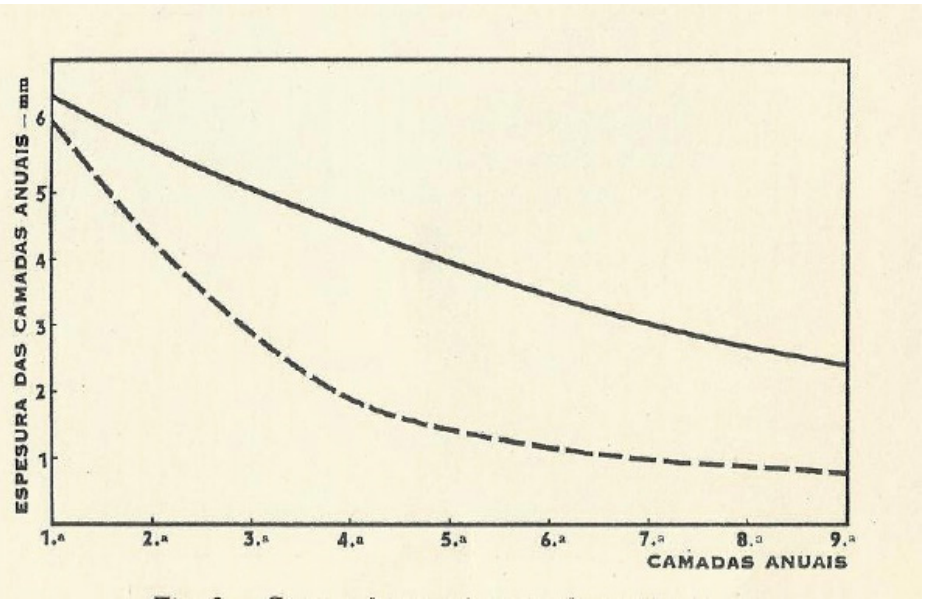

Source: (Natividade, 1951: 4).

Note: The solid line represents cork growth from a cork oak forest without agriculture practices for the last 40 years; the dashed line represents cork growth from a cork oak forest exposed to the competition from cereal culture. The $Y$ axis represents, in millimetre, the thickness of the annual cork layers, and the $X$ axis the number of years.

Besides affecting cork production, soil degradation led to higher mortality among grown cork oaks trees due to lower resistance to diseases, pests, and premature aging. In younger trees, it disfavours their growth, increases mortality and, therefore, affects the natural regeneration of the cork oak ecosystem considerably, the primary «method» of creating new cork oak forests in the $19^{\text {th }}$ century (Natividade, 1951: 12; Faísca, 2019b: 103-106).

The main action responsible for the scenarios described was the agricultural use of the soil that led to the destruction of the plants under the trees and to the periodic mobilizations of the soil. In the absence of small plants under the trees, the soil was exposed to the Mediterranean climate's typical wide thermal variations. This meant excessive heating and dryness in the dry season, while during winter the concentration of rainfall washed away part of the soil, which further reinforced its impoverishment (Natividade, 1950: 124). Vieira Natividade was peremptory in stating that what was demanded of the tree was more than reasonable, while it was more than it could give from the soil (Natividade, 1951: 4). Another renowned forest engineer, Jaime Salazar Sampaio, noticed the same when he studied, in 1951, the cork oak forest of Grândola, a municipality in the core of the cork oak forests of Southern Portugal. The degradation of the soils in the Montado also meant that any crop had to be preceded by a long fallow of no less than 6 years in the best lands and 8 in the poorest ones. A wheat crop, because is quite demanding of the land, was almost impossible to utilise (Zapata Blanco et al., 2012: 27). The 
consequences described above - namely, decrease in the quantity and quality of cork - can have a negative impact on the entire cork industry at any historical time, but even more so in the $19^{\text {th }}$-century cork business.

Currently, the extracted cork from the trees can be used to manufacture a wide range of products. Within the cork stoppers, the principal product of this industry, there are the natural cork stoppers that, from a single piece from a corkboard, constitute a uniform stopper without the use of any other type of technique. Then, we have the technical cork stoppers. These result from a combination of a natural cork disc, the only part that comes into direct contact with the bottled liquid, with a body of cork agglomerate. In this way, the central core of the stopper comes from the use of waste generated in the manufacture of natural cork stoppers and/or of cork of the lowest quality and without calibre for the production of natural cork stoppers, while the extremities are made of natural cork. Finally, there are total agglomerated cork stoppers, the ones with less economic value, originated in the same way as the body of the technical stopper. In addition to the production of stoppers, the cork industry has specialized in the manufacture of a wide range of products, with emphasis on insulators for civil construction, since the invention of the agglomerate. However, in the $19^{\text {th }}$ century, cork agglomerate was not yet used as it was only invented at the end of the century. In the Iberian Peninsula, cork agglomerate only began to be produced significantly after the First World War (Flores, 2003: 60; Filipe and Afonso, 2010: 39; Parejo Moruno, 2010: 37-38). Therefore, in the $19^{\text {th }}$ century, the cork industry could only work with natural cork stoppers. This meant that not only the corks with the largest calibre had industrial use but also the quality of cork was, even more than today, a fundamental factor in the manufacture of stoppers, since the worst categories could originate stoppers with their sealing functions compromised. Additionally, corks without quality and waste did not have any industrial use, which devalued these products immensely. Thus, the quality of cork, a crucial aspect today, was fundamental in the $19^{\text {th }}$ century.

Besides quality, the loss of vigour of the cork oak trees and, ultimately, their death reduce the amount of cork that can be extracted from each tree. This is particularly relevant because the supply of raw material is one of the most critical aspects of the cork industry, essentially because it is the main cost factor of the entire industry. For instance, in the 19th-century cork industry, the raw material corresponded to more than 70 per cent of the cost structure. That was true even in manufacturing units where the productive logic had already replaced, at least in part, labour intensive for capital intensive production (Faísca, 2019b: 168-169). With such preponderance, the possibility for the cork industry to have cork at competitive prices was decisive for achieving commercial success in international markets that absorbed the vast majority of Iberian cork products (Parejo Moruno, 2010: 59).

The domestic supply of raw material, by its turn, depends on the national forest production of cork and on the customs policy that can prevent or facilitate 
the export of raw cork to other countries. In the case of the two Iberian countries, during the period under examination here, the policy regarding the export of raw cork was relatively free, sometimes with the absence of any obstacles, sometimes with the imposition of low customs tariffs (Faísca, 2019b: 240-252). There were, however, two exceptions. In Spain, in the Catalonia region, where most of the Spanish cork industry was located, the export of raw cork was heavily penalized or even banned until 1877. From then on, it still paid a customs fee. However, most of the forestry production of cork in Spain was in Southwest regions, essentially Andalusia and Extremadura. In these, except for 1876-77, the exports of raw cork were always facilitated. In Portugal, the export of raw cork did not have any major restrictions until 1910. From then onwards, all cork that was not cooked, scraped, cut, and duly bandaged could not be exported (Flores, 2003: 158-159). Therefore, in the 19th century, both Spain and Portugal presented similar policies regarding exporting raw cork. This meant that significant differences between the two countries concerning the supply of prime matter were restricted to each national production, which, among other issues, depended on the use of cork oak forest soil.

It is noteworthy to explain that cork sustained an important economic sector for both countries during this historical period, as it was one of the main contributors to exports in Spain and in Portugal. In the latter, cork, either raw or industrially transformed, became, in a little more than half a century, the second most important item of the country exportations from a share of 2.6 per cent of the total Portuguese exports in 1850, to 12.4 per cent in 1914 (Lains, 2003: 75). Only wine had a bigger share. In Spain, the importance of the cork sector in exportations was smaller, but nevertheless the share of the exports of cork was around 3 per cent of the total, far from being of little relevance (Parejo Moruno, 2010: 19). It also supported about 1,250 factories which employed over 36,000 Spanish workers at the end of the $19^{\text {th }}$ century (Parejo Moruno, 2010: 88).

Consequently, the economic importance of cork in rural proprieties grew quickly over the 19th century. The list of authors who have referred to it, whether writing at that time or more recently, is vast. Silva Picão, for instance, claimed in 1903 that "Nobody ignores how much cork is demanded and paid with prices that would look fantastic to our grandparents" (Picão, 1947: 42). In the same sense, economic historiography identified cork, from the mid-19th century onwards, as the main product of the primary sector of the Southwest of the Iberian Peninsula (Serrano Vargas, 2007; Martins, 2005; Parejo Moruno, Faísca and Rangel Preciado, 2013; Branco and Silva, 2017). In the specific case of Portugal, cork represented the highest growth rate of all agroforestry products between 1870 and 1930 (Branco and Silva, 2017: 222). Thus, the ability for producing cork became the major factor for calculating the market value of rural proprieties (Martins, 2005: 246). In fact, in several statistics that present the revenue of forestry products, cork is the most 
valued element. It is the case of two municipalities in Southern Portugal, as shown in Table 1.

Table 1: Gross average income by forest product in the Montados in late $19^{\text {th }}$ century

\begin{tabular}{|l|r|r|r|r|}
\hline \multicolumn{1}{|c|}{ Municipality } & Corn & Cork & Wood & Pasture \\
\hline Santiago do Cacém (1894) & $13.17 \%$ & $76.03 \%$ & $4.96 \%$ & $3.16 \%$ \\
\hline Odemira (1891) & $17.33 \%$ & $79.71 \%$ & $3.87 \%$ & $2.77 \%$ \\
\hline
\end{tabular}

Source: Calculated from the following documents: for Santiago do Cacém, Arquivo Nacional da Torre do Tombo, Ministério das Obras Públicas, Comércio e Indústria, Direcção-Geral de Agricultura, NP 901, Doc. 19; for Odemira, Arquivo Nacional da Torre do Tombo, Ministério da Agricultura, DirecçãoGeral de Economia e Estatística Agrícola, Caixa 283, Maço 14.

Also, when compared with husbandry or other crops, cork production is one of the most economically valued resources, if not the most valuable one. This can be noted in Tables 2 and 3 respectively, for example in the municipality of Alvito where the net average income is more significative than the one from the husbandry of pigs.

Table 2: Net average income in the Montados of the municipality of Alvito (1884)

\begin{tabular}{|l|r|r|r|r|r|}
\hline & \multicolumn{3}{|c|}{ Husbandry (Pigs) } & \multicolumn{2}{c|}{ Cork } \\
\hline Parish & $\begin{array}{c}\text { Surface } \\
\text { (Hectare) }\end{array}$ & Number of pigs & $\begin{array}{l}\text { Value } \\
(\text { Réis })\end{array}$ & Production & $\begin{array}{r}\text { Value } \\
(\text { Réis })\end{array}$ \\
\hline Alvito & 3.515 & 1.230 & 7.380 .000 & 248.000 & 14.880 .000 \\
\hline Baronia & 2.160 & 712 & 4.272 .000 & 1.978 & 2.100 .000 \\
\hline Total & 5.675 & 1.942 & 11.652 .000 & 283.000 & 16.980 .000 \\
\hline
\end{tabular}

Source: (Pery, 1885: 36).

Then, when compared with all the main grain crops, cork presented a net income per hectare higher than any - wheat, barley, rye, oats and maize - with the exception of rice. However, rice cultivation was restricted to the existence of stable supply of water, which in the cork regions of the Southwest of the Iberian Peninsula was something that was found only in very few places, unlike the cork oak. 
Table 3: Net yield per hectare, expressed in réis, of grain crops, cork, and olive oil in Santiago do Cacém and Alvito in late $19^{\text {th }}$ century

\begin{tabular}{|l|r|r|}
\hline Crop/Product & Santiago do Cacém (1894) & Alvito (1884) \\
\hline Rice & 20.430 & - \\
\hline Cork & 9.585 & $\mathbf{1 1 . 8 0 0}$ \\
\hline Maize & 8.870 & 7.800 \\
\hline Wheat & 8.035 & 3.526 \\
\hline Olive oil & 6.585 & 9.777 \\
\hline Barley & 4.620 & 4.026 \\
\hline Oats & 3.650 & 3.165 \\
\hline Rye & 3.225 & 2.328 \\
\hline
\end{tabular}

Source: For Santiago do Cacém, the same as Table 1, and for Alvito the same as Table 2.

\section{Sources and methods}

As far as we know, sources that describe the cultural practices in the soils of cork oak forests in the Iberian Peninsula of the $19^{\text {th }}$ century are scarce. Notwithstanding, it is possible to gather information from different types of sources. On the Portuguese side, here we use mainly official reports written by specialized technicians - agronomists, civil engineers, geologists, etc. - working for the Portuguese state and the published memoirs of an important Alentejo farmer and landowner. Describing these sources in chronological order, the survey of the state of the cork and holm oak forests in the municipality of Ponte de Sor, located in one of the main regions of forestry production of cork in Portugal - Alto Alentejo -, appears first. This document, produced by the Comissão Geológica e Mineralógica ${ }^{5}$, directed by the Civil Engineer Charles Bonnet, dates 1851. It resulted from several journeys that this commission did to the Alentejo to produce an exhaustive survey of the region for the future publication of the Physical and Geological Map of Portugal (Leitão, 2004: 58). Although the Map was not completed during this commission, it generated a great deal of knowledge about the physical geography in the south of Portugal, including forests and agricultural use of the soil. A similar situation occurred with the information obtained in the official publication of the Direcção-Geral de Agricultura - the State organism for the Portuguese Agriculture - the Boletim da Direcção-Geral de Agricultura. The similarities between the two documents are remarkable, since the latter was produced in the context of several journeys made 
by a team led by Gerardo Pery, in the 1880 s and 1890 s, to complete the Agriculture Map of Portugal, which they never did.

Nevertheless, provisional results were published and those are the ones we gathered information from. Moreover, António Filipe da Silva, the agronomist of the Portuguese State to the Portalegre district, signed an extensive report in 1904 that focused only on the cultural practices of the cork oak forests in Alto Alentejo, on which we have based a significant part of our analysis. Finally, among other sources with less information, we used the work of the farmer and landowner José da Silva Picão, published the first time in 1903, which describes the Alentejo agricultural practices and several other aspects of rural life (Picão, 1947).

On the Spanish side, due to the existence of a more significant number of studies on this topic, we used exhaustively contemporary bibliography published by major authors. They studied the cork oak forests from forestry, economic, or economic history perspectives. These were the cases of the works of Antonio Linares, Santiago Zapata Blanco, Pablo Campos, or Gregorio Montero, among others (Linares Luján and Zapata Blanco, 2003; Pulido, Campos and Montero, 2003). Regarding 19th-century sources, we analysed the book of Salvador Céron (1879), a renowned Spanish Forestry Engineer and Botanist, on the agroforestry sector in the Andalusian province of Cádiz, as well as dozens of lease contracts of raw cork recorded in the Public Notaries of several villages in Extremadura (García García, 2006; García García, 2008). The latter includes information on the existence of agricultural practices in cork oak forests in the various clauses that regulated the cork extraction. Finally, we used a chorography, the Diccionario geográfico-estadístico-histórico de España y sus posesiones de Ultramar, written by Pascoal Madoz (Madoz, 1845-50). Composed of sixteen volumes, this Dictionary is considered one of the most complete works on the knowledge of Spanish territory in the middle of the $19^{\text {th }}$ century.

Having described the main sources, it is critical to explain the geographical area in our analysis. We looked into the main regions of the Iberian Peninsula where cork oak grows. These are, in Portugal, Alentejo and, in Spain, Extremadura and Andalusia. In this article, Alentejo corresponds to the sum of the current Nomenclatures of Territorial Units for Statistical Purposes (NUTS III) that presently uses this designation- Alto Alentejo, Alentejo Central, Alentejo Litoral and Baixo Alentejo. In the $19^{\text {th }}$ century, as nowadays, it was the main Portuguese raw cork producer region consisting of, at the beginning of the $20^{\text {th }}$ century, more than 260 thousand hectares of cork oak forest of a national total of just over 366 thousand, thus approximately 71.47 per cent (Pereira, 1915: 275-276). In Spain, it is also in the autonomous communities of Extremadura and Andalusia that most the cork oak areas were located. In 1888, according to Primitivo Artigas, the cork forest area in Spain was 255 thousand hectares, of which almost 100 thousand hectares were found in these two autonomous communities, with 80 thousand being in Catalonia, especially in the province of Gerona (Artigas y Teixidor, 1888: 283). However, in 
Catalonia, the cork forest areas are concentrated-Sobreirais or Alcornocales - and not extensive- Montados or Dehesas - where there is not an agro-silvo-pastoral exploitation logic. Thus, circa 40 per cent of the total area of cork oak forest in Spain at the end of the $19^{\text {th }}$ century was located in Extremadura and Andalusia, but when considering only the cork oak forests extensively explored, the figure rises to almost 60 per cent of the total. Therefore, analysing Alentejo, Extremadura and Andalusia, the vast majority of the cork oak forests areas extensively explored in the Iberian Peninsula are covered.

\section{The use of the soil in the cork oak forests of the Iberian Peninsula}

Beginning with Portugal and, therefore Alentejo, one of the best sources to understand the use of the soils of the cork oak forests in the $19^{\text {th }}$ century is undoubtedly a testimony written by António Filipe da Silva, the State agronomist for the district of Portalegre, in $1904^{6}$. It is important to note that, besides being a document written by a highly specialized technician, it also reports on one of the core regions of the cork oak forests in Portugal. As a matter of fact, the district of Portalegre, which currently corresponds to the NUTSIII region of Alto Alentejo, had, at the beginning of the 20th century, the largest NUTSIII area of cork oak forest in Portugal, with more than 71 thousand hectares (Pereira, 1915: 275-276).

This source confirms the existence of the several agroforestry practices that harmed the development of the trees, much like the ones pointed out by Vieira Natividade. Thus, to the question "what is the number of cultural operations since the clearing or sowing until the adult age for a cork oak tree?"7 the agronomist describes the deforestation of all plants with more than $15 \mathrm{~cm}$ in height. António Filipe da Silva acknowledges that this action caused a massive loss of organic matter in the soil. Even worse was the cultivation of grains that required the deep mobilization of the soil to grow crops like wheat or rye. The consequences were the ones already mentioned and that nowadays the Portuguese legislation forbids ${ }^{8}$. Returning to the document, it states that the next operation again involved the sowing of wheat or rye and, after the harvest, in October of the following year, more digging of the soil was done for a new crop, using now the grain that was not used before. Additionally, whenever necessary, the pélas were made, which is, once again, the pulling out of the plants by hand or with the aid of sachets, done by a group of women as soon as the plants began to reappear. At the end of the harvest of the second year, due to the exhaustion of the soil, a fallow period of four

6 The document can be found in Arquivo Nacional da Torre do Tombo, Ministério das Obras Públicas Comércio e Indústria, Direcção-Geral de Agricultura, Maço 977, Processo 161.

7 In original Portuguese language "Qual é a série d'operações culturaes desde o desbravamento, ou sementeira até à idade adulta do sobreiro?".

8 The Decree of Law n. $11 / 97$ prohibits any deep soil mobilization that can affect the root system of trees and destroy the natural regeneration by mechanical or other means. 
or more years began, so that finally the soil could acquire some fertility from the microorganisms that decompose organic matter and promote the fixation of the atmospheric nitrogen. However, according to Vieira Natividade, the attenuation of the harmful effects done on the soil due to the cultivation of cereals with the fallow was manifestly insufficient. Firstly, the duration of the fallow, even if more than four years, was too short to restore any reasonable amount of fertility, but, above all, when the plants were successively pulled out, it left only thin vegetation that only gave the soil precarious protection. In the context of the Mediterranean climate, this situation led to the total calcination of the soil by the hot sun in the long summer and, in the rainy season, the soil that remained was washed away by the rain (Natividade, 1951: 10). This led to a reduction in the humus content, which, in the long run, would not only lower the yields of any cereal culture, but also harm the quality and quantity of the cork production (Natividade, 1951: 11).

Regarding fertilization, the scenario described by Vieira Natividade almost half a century later was already present, since António Filipe da Silva recommended that the farmer should only use the fertilizers that were already used in the cereal crops present in the interspersed areas of the cork oak forest. He stated that any amount that exceeded the cereal's requirements would be enough to stimulate vegetative activity with the help of substances made by microbes present in the soil. The fertilizers were used only due to presence of cereal crops and not to help the cork oak tree and/or the growth of cork. Finally, the agronomist claimed that, beyond weeding and giving some protection to young trees from cattle, no other care was given to the cork oaks. Therefore, the scenario was not favourable to capture the whole potential for growing the best quality cork. António Filipe da Silva himself recognized his lack of scientific knowledge on the cork oak forests because neither had he analysed, experienced, or gained any specific knowledge that could guide him. Thus, he used the works of M. Wagner, director of the Darmstadt Agronomic Station in Germany, which concentrated on the fruit trees as a proxy to cork oak trees.

The agricultural monograph of Moura - a municipality in Baixo Alentejo with some cork production - published in 1894 also identifies the heavy agriculture practices in the cork and holm oaks forest. In the most populous parishes in the interspersed areas of cork oak, holm oak and olive trees, the land was being cultivated with wheat, barley and oats in a total of 7,605 hectares (Portugal, 1894: 212). D. Luiz de Castro, an agronomist and future Minister, claimed that the cork oak forests should be sowed with any grain that the land could accept well (Castro, 1892-1893: 177). Moving on to primary sources, the lease contracts for cork extraction are full of information that indicates the multiple uses of the land of cork oak forests for grain crops when, for instance, warns the cork strippers that they have 
to be careful not to damage the crops $^{9}$. A statistical survey dated 1851, produced by the Comissão Geológica e Mineralógica, is more than clear that in almost all the cork oak forests of the Ponte de Sor municipality, in Alto Alentejo, a cereal culture coexisted with the trees. This municipality was the one with the largest cork oak forest area and with the highest forest production of cork in Alto Alentejo. Thus, of more than 4,415 tons of cork extracted in Alto Alentejo, in 1905, 800 tons, or 18.12 per cent, came from the municipality of Ponte de Sor ${ }^{10}$. As shown in Table 4, of 63 cork oak forest proprieties, 53 were pure and ten were mixed with holm oak; only ten did not have any cereal crop. Regarding the type of crop, rye predominated, followed by corn and there were still three wheat production case.

Table 4: Crop production in cork or holm oak forest properties (1851)

\begin{tabular}{|l|r|}
\hline Properties with wheat & $3(4.35 \%)$ \\
\hline Properties with maize & $15(21.74 \%)$ \\
\hline Properties with rye & $53(76.81 \%)$ \\
\hline Properties without any cereal crop & $10(14.50 \%)$ \\
\hline Pure cork oak properties & $53(76.81 \%)$ \\
\hline Pure holm oak properties & $6(8.7 \%)$ \\
\hline Pure cork oak properties or with cork oak areas & $63(91.30 \%)$ \\
\hline Total number of properties & $69(100.00 \%)$ \\
\hline
\end{tabular}

Source: Arquivo Histórico Municipal de Ponte de Sor, Administração do Concelho de Ponte de Sorr, Correspondência expedida, 1851.

Note: Some proprieties had more than one crop at the same time.

Finally, the farmers not only described these practices, but also presented them as good examples of managing cork oak forests. José da Silva Picão, an important farmer in a border region between Portugal and Spain, in Elvas Municipality, confirmed that partial or total destruction of the plants was recurrent. Picão, further, recommended the absolute pulling out of the plants to allow the maximum use of the land in the interspersed areas through cereal cultivation - the so-called clearings or uproots. The only lament of this Alentejo farmer and landowner was the low frequency of clearing due to the high cost resulting from the intensive use of labour and in cases where this does not even occur due to the scarcity of resources of smallholders or the lack of interest of short-term tenants (Picão, 1947: 34). Therefore, Silva Picão concluded that with these practices "(...) everything profits, including the land, which is also used in the cultivation of cereals (...)", since "(..)

9 This document in available in Arquivo Distrital de Évora, Cartório Notarial de Montemor-O-Novo, Livro 124, fl. 135.

10 This information is available at Arquivo Nacional da Torre do Tombo, Ministério das Obras Públicas, Comércio e Indústria, Direcção-Geral de Agricultura, NP 853, Doc. 144. 
the cork oak forests who benefit from cleaning radical and persistent show a luxuriant appearance" (Picão, 1947: 34-36). In conclusion, official reports, primary sources and the farmers' opinions point towards a scenario where the management of the soil in Alentejo, the main region of Portugal of cork oak forests, was not the most favourable for the total harnessing of the potential of raw cork production.

Nevertheless, on the Spanish side, the scenario seems very similar to the Portuguese one. Authors and sources confirm an increase in the agricultural use of the cork oak forest soil during the period in question. Considering that, during the $19^{\text {th }}$ century, there was a widespread expansion of the area of cultivation in the Spanish southwest, with a particular focus on cereal culture, a situation of this kind would be expected. Thus, in Extremadura alone, it is estimated that about one and a half million hectares had been added to the cultivated soil in the region (Linares Luján and Zapata Blanco, 2003: 19). As in Portugal, cereal protectionism, as it will be shown later, exerted pressure on forest exploitation, increasing ploughing in the cork oak forests. However, in a period when cork and livestock also experienced a strong appreciation, the solution was to intensify the agro-silvo-pastoral logic, making the cork oak forests more agricultural, with more livestock and with more cork exploitation than before (Linares Luján and Zapata Blanco, 2003: 23; Ezquerra Boticario, 2009: 6). The conclusion seems clear, during the second half of the 19th century, in Extremadura and Andalusian regions, there was an increase in cultivated areas, especially cereals, as well as the adoption of shorter rotations, which meant an increase in the agricultural component of these forest areas (Zapata Blanco, 1986: 981).

Consequently, there was a growth in the soil wear risk, just like Vieira Natividade pointed out for Alentejo and the $19^{\text {th }}$-century sources confirmed. In fact, the Spanish authors of the $19^{\text {th }}$ century recommended the complete extraction of all plants, claiming that this work on the soil is not only convenient, but also necessary so that trees could grow better and reduce the risk of fire (Pulido, Campos and Montero, 2003: 33). However, bare soil was subject to substantial variations of the Mediterranean climate with adverse effects on soil fertility, leading other Spanish specialists, such as agronomist Ramón Paredes, in 1875, to advise prudence in the way agricultural expansion was carried out. He feared, especially, that it could led to high deforestation and, consequently, the impoverishment of the soil (Linares Luján and Zapata Blanco, 2003: 21).

Moving now to specific cases, it is apparent that from the end of the $18^{\text {th }}$ century, in the cork and holm oak forests of Azuaga, province of Badajoz, Extremadura, the grazes became more frequent. With a periodicity of two to three years, the objective was sowing wheat, rye, and barley, by this order (Gallego Fernandéz and García Novo, 1997: 34). The ecological consequences were such that, in the 20th century, the mountainous area in the south of the region became a secondary forest system, with soils subject to great erosion (Gallego Fernandéz and García Novo, 1997: 42). Like in Portugal, several cork lease contracts referred to the 
ploughing and cereal use of the soil. For instance, in 1853, in Cabeza de la Vaca, province of Badajoz, Extremadura, a contract stated that "(...) within the circle that comprises the sown area it will not be possible to extract and pack the cork up until the farmers do the harvest of the crop. (...)" (García García, 2006: 73). There are several examples regarding the ploughing of the soil, but we wish to highlight a contract, concluded in Jerez de los Caballeros, province of Badajoz, Extremadura, in 1865. In this document, it is stated that "(...) being of the responsibility of the tenant the cleaning of the cork oaks in the necessary part, so that it produces cork (...) when the land is ploughed, the owner, D. Angel Esteban Sánchez, can clean the branches (...)" (García García, 2008: 60). Meanwhile, in the province of Cádiz, in Andalusia, a source reports the proliferation of grazes and fires to obtain a "clean" land suitable for annual crops, making more than 20 thousand hectares populated with cork oak trees sterile and "(...) exposed in all their nudity to the devastating effects of climatic agents (...)" (Cerón, 1879: 89).

Finally, in the seminal work Diccionario geográfico-estadístico-histórico de España y sus posesiones de Ultramar, published between 1846 and 1850 by Pascual Madoz, references to situations as the ones we have described are multiple and transversal to the entire Spanish Southwest. To name a few examples, in Zafra, province of Badajoz, Extremadura, a propriety that contained about 5.500 holm oaks and 6.000 cork oaks had several plants like rock rose, broom, mastic, rosemary, heather, among other bushes, that were grazed and burned to prepare the soil to sow with wheat and barley (...)" (Madoz, 1850: 442-443). Further north in Cerezo, province of Cáceres, still in Extremadura, but circa $250 \mathrm{~km}$ from the previous example, there was also a property "(...) populated by holm oak and cork oak trees, which is sowed every three years (...)" (Madoz, 1847: 330-331). In the south, to focus on an Andalusian case, in Beal de la Jara, province of Seville, the Sierra Morena is "(...) populated with holm oak and cork oak trees, with little production, because to be able to sow it is necessary to create a propriety with graze and burn of the bushes (...)" (Madoz, 1847: 379).

We can conclude that although there is some scarcity of historical sources, the available information suggests that in the Spanish southwest the problems identified in Alentejo were the same. Concretely, due to the strong agricultural use of the interspersed areas of the cork oak forests, there were periodic mobilizations of the soil, the extraction of all the plants or, at least, with that intention, and a regular cereal crop, especially of wheat and rye, which probably competed with the development of the cork oak and enhanced soil depletion. Recent studies have been reaffirming the negative consequences for the soil, since the second half of the $19^{\text {th }}$ century, as a result of the intensification of agricultural practices that, in many cases, have broken the balance of the agro-silvo-pastoral ecosystems. The total suppression of vegetation, the reduction of manure and the use of nitrogen-deficient fertilizers led to an erosive process and the breakdown of organic matter, 
impoverishing the soil with consequences that extend to the present day (Carmo, 2018: 47-51).

\section{Institutional and political context of the $19^{\text {th }}$ century in Spain and Portugal: Behind the misuse of the soil of the cork oak forests}

The Iberian cork oak forests scenario was quite similar and reflected at least three probable causes felt in very analogous ways on both sides of the border. First, there was a general scarcity of scientific studies and a lack of qualification regarding the cork oak forests among specialized technicians in both countries, which is confirmed, for example, in the words of the agronomist of the district of Portalegre. Then, there was also a deficiency of knowledge about the cork oak ecosystem by farmers, something we can extract from the memories of Silva Picão, which probably is related to a deficient primary and secondary educational system. Finally, there were strong state incentives for cereal production in Spain and Portugal in this historical period and, simultaneously, an absence of legal protection and/or any incentive in the forestry policy for the cork oak tree.

The first two issues are related as they come from the underdevelopment of education and the scientific research about cork oak forests, both in Spain and Portugal, in the 19th century. In reality, the scientific research on the Mediterranean forest, where the cork oak tree is included, was almost inexistent. In forestry education, contents related to these trees were of little relevance (Faísca, 2019b: 290-307). Both situations had the same origin, the large influence that dasonomy, the forest science developed in Germany, had on Iberian forestry until the beginning of the 20th century. A good part of the first Portuguese and Spanish foresters was trained in German schools or were strongly influenced by German forestry education (García Pereda, 2018; Faísca, 2019b: 306). In the absence of Mediterranean species in German territory, as is the case of the cork oak, dasonomy did not include them, so the research and teaching propagated by Portuguese and Spanish forest engineers did not consider the harmful effect of the practices. In fact, as already mentioned, António Filipe da Silva, with a Degree by the Agrarian Superior Institute of Lisbon, recognized this gap by supporting his answers on cultural techniques in the cork oak forests of Alto Alentejo in German bibliography. In Spain, the situation was similar, just like Primitivo Artigas, one of the few Spanish experts on the cork oak at the time, recognized in 1875. He claimed that "(...) although this species [the cork oak] is one of the most profitable ones, it has not yet been sufficiently studied under a dasonomical point of view, not even has been applied to these trees the scientific precepts that the physical-natural sciences advice" (Artigas y Teixidor, 1875: 27). In addition to the lack of education on cork oak forests, the number of Iberian forest engineers was limited for the size of the territory, especially in the Portuguese case where they did not exceed a dozen at the beginning of the $20^{\text {th }}$ century (Radich and Alves, 2000: 94). Additionally, among the few forestry 
engineers working in Iberian forests, their actions were directed to other problems, so even few who were assigned to areas of cork oak forests only achieved practical results well into the $20^{\text {th }}$ century. The chronic scarcity of means and, once again, the lack of adaptation between dasonomy taught to them and the valorisation of the Mediterranean forest wealth, dictated it (Linares Luján, 2002: 570-573).

Outside of higher education and scientific research, at basic and secondary education levels, where farmers like Silva Picão could acquire knowledge about the cork oak trees, the panorama was also not encouraging. First of all, it should be noted that the implementation of an educational system with reasonable national coverage suffered from a chronic lack of financial resources that affected the Iberian States throughout the $19^{\text {th }}$ century. Additionally, forestry education, which was often included in agricultural education, was of little importance, while cork oak contents were practically non-existent (Faísca, 2019b: 290-307). A good example is the creation of the Portuguese Practical Agriculture Schools network in the late 1880s, intended for elementary agricultural education. Of the six that opened to the public, in only one, in Portalegre, the study plan presupposed the existence of a discipline related to cork oak forests. However, this school had a short life of only six years, therefore predictably with little impact on the formation of managers of Portuguese cork oak forests (Faísca, 2019b: 293-294).

Farmers and other agricultural workers with less formal education are represented in higher illiteracy rates in rural areas, and less frequency in schools (Faísca, 2019b: 304-305). In Table 5, we can find the example of Badajoz's secondary school, Extremadura, where, according to the fathers' profession, the students of agricultural background are the less numerous.

Table 5: Number of students registered in Badajoz's secondary school, according to the fathers' profession (1877-1900)

\begin{tabular}{|l|r|r|r|}
\hline Professional sector of the father & 1877 & 1887 & 1900 \\
\hline Agriculture & 0,15 & 0,21 & 0,22 \\
\hline Industry & 0,39 & 0,52 & 0,48 \\
\hline Commerce & 0,72 & 1,40 & 1,90 \\
\hline Liberal professions & 5,30 & 10,33 & 12,15 \\
\hline Public workers & 3,24 & 3,02 & 7,80 \\
\hline
\end{tabular}

Source: (Sánchez Pascua, 1985: 123-125).

Note: The numbers match the number of students for each one thousand workers in each professional sector. 
The lack of research and educational content about cork oak trees in Iberian countries is also a consequence of forestry policies aimed at other problems than the growth and improvement of cork production. In reality, Portugal and Spain's forestry policies were conditioned by the interests of agriculture and, once again, by the German dasonomy. Thus, the state's efforts in forestry matters were oriented towards the fixation of dunes and mountain soil to prevent the expansion of sand to agricultural land and, in the latter, to regularize river flows and stop the subsidence of land over crops (Faísca, 2017: 25). At the same time, from the 1870s, in Spain, and the 1880s, in Portugal, an agricultural policy of strong protection of domestic cereal production was implemented. Either by fixing administrative prices, imposing high import tariffs, or both, the Iberian states began in the second half of the $19^{\text {th }}$ century a policy to promote cereal cultivation that extended almost until the late $20^{\text {th }}$ century. In Iberian agriculture, wheat was the most protected cereal, precisely the most widespread in the drylands of the Southwest Peninsular regions populated by cork oaks trees. This way, the Iberian agricultural policy promoted the dispute by the cereal culture over territories and natural resources with the cork oaks trees, harming the forest production of cork according to the examples cited in this work (Costa, Miranda and Lains, 2011: 307-308; Faísca, 2019b: 261290). In reality, it was nothing new, since both States followed a secular concern of the populations of the Mediterranean areas of the Iberian Peninsula: agriculture soil was seen as more important than forests, with the trees being often destroyed due to the agricultural needs of the populations (Branco, 2005: 63).

\section{Conclusions}

Contrary to what has been occurring since, roughly, the mid-20 $20^{\text {th }}$ century, in the 19th century the world leader in the cork business was Spain and not Portugal. This happened despite the potential advantage in the supply of cork by Portugal, which is due to edaphoclimatic reasons, a key factor for competitiveness in a business where around 70 per cent of the industry's cost structure was derived from the raw material. Several factors might explain Spain's leading position. In this article, we focused on the supply of raw material both in quantity and quality, based on the influence of the use of the soil of the cork oak forests on the cork produced there. This aspect is mentioned in the Portuguese cork oak bibliography, published in the middle of the $20^{\text {th }}$ century, as one of the main causes of the reduction, both qualitative and quantitative, of the cork's potential in Portugal and with a historical background. We questioned whether the $19^{\text {th }}$-century sources confirmed what half a century later was claimed and, from a comparative perspective, whether the cork oak trees also suffered from the same problem in Spain. If not, that would be an advantage that could help explaining the better performance of the Spanish cork 
business in the $19^{\text {th }}$ century. However, the main conclusion of this study is that, both in Portugal and Spain, the harmful agricultural practices- soil mobilization, excessive deforestation, intensive cereal cultivation, among others - were common. We did not identify, by the way the soil was treated, any advantage for the Spanish cork business, neither any disadvantage. We identified a set of practices with negative effects in the medium and long term from an economic point of view, for the reasons mentioned and from an environmental one. In this case, the practices identified probably led to the impoverishment of soils and the land use breakdown. In fact, this is precisely what Vieira Natividade and Jaime Salazar Sampaio, two renowned Portuguese scientists and forest engineers, noticed for the Portuguese Southern Region of Alentejo in the $20^{\text {th }}$ century. They would most likely have reported the same problems if they had studied the Spanish Southwest's cork and holm oak forests with the similar detail.

When we look into Spain and Portugal's political and institutional context in this historical period, it is without any doubt that the agroforestry practices of the two countries were, at least, quite similar, since the whole framework was also very similar. Scientific research on the cork oak ecosystem was underdeveloped due to, among other aspects, the influence of German dasonomy on Iberian forestry. Designed to be applied in Central Europe's forests, forest science in vogue in the $19^{\text {th }}$ century was not prepared to deal with the specificities of Mediterranean forests, especially with the multifunctional systems of the cork and holm oak forests. In addition to science itself, dasonomy was also present in forestry higher education in Spain and Portugal, which influenced Iberian agronomists and foresters. At the other levels of education, more likely to be attended by farmers and landowners, forestry content was hardly taught in a system that, in turn, had little representation in rural societies of Spain and Portugal. At the same time, the Iberian agricultural policy favoured cereal cultivation, encouraging it in the cork oak forests. Moreover, the forestry policy did not protect the soils of the cork forest areas contrary to what currently occurs.

In sum, economically all the potential for cork production was not fully explored and, ecologically, the soil depletion probably favoured regional environmental, economic and, consequently, human desertification, since the land lost a part of its fertility. Ecologically, the soil became more vulnerable to erosive processes, especially rainfall erosion, with negative impacts on ecosystems and on rural landscapes, that are still felt today (Gonçalves, 2017). Particularly, the consequences covered the weakening of the potential for oak forests, the loss of shrub biodiversity and, indirectly, of fauna. Despite the conflict between the use of intensive agricultural land and forest soil in cork oak forests, which only began to be discussed systematically well into the $20^{\text {th }}$ century, the truth is that it was already noticed earlier. For this reason, in 1915, the preliminary draft of the constitution of the Union of Portuguese Cork Producers, a production cooperative, mentioned 
it. The document considered it a positive that "(...) the government, through the Inspection of Forest Services, establishes the necessary penalties to avoid (...) that, due to the exaggerated treatment of the cork oak soil (...), the good quality of cork is harmed (...)" (Pessanha, 1915: 12).

Therefore, what explains the preponderance of the Spanish cork industry in the $19^{\text {th }}$ century despite the advantage of Portugal in the supply of raw material which, as we saw, was not exploited in a more harmful way in any of the two countries? A recent $\mathrm{PhD}$ thesis argues that the idea of an underutilization of the Portuguese cork potentialities, claimed by many authors of the time (Nunes, 1905; Cabreira, 1914), is somehow a biased perspective (Faísca, 2019b: 320-321). As a matter of fact, the Portuguese cork sector evolved, in less than a century, from its birth to world leadership. This happened in a very competitive market in which some of the most industrialized countries on the planet participated. Being in one of the most peripheral economies of Europe, the $19^{\text {th }}$ century seems more an initial stage of a success story for the Portuguese cork business than otherwise. It should be noted that the Spanish cork business was already established in the middle of the $18^{\text {th }}$ century, while the Portuguese didn't really start until a century later. Additionally, Spanish industry, concentrated in Catalonia, combined closeness to large consumer markets, such as France, with proximity to raw materials. Around mid-19 ${ }^{\text {th }}$ century, Spanish corks already had a high prestige in foreign markets. Nevertheless, throughout this period the Portuguese cork business grew continuously and also changed its structure, from supplier of raw material to seller of industrial products, generating a growing increase in domestic retained added value. Thus, the added value of the cork industry went from 1,1 per cent of the total added value of the Portuguese industry in 1850 to 7 per cent in 1910; the number of industrial workers, in the same period, grown from 164 to 6.634 (Lains, 2003: 138); and, finally, the industrial exports changed from a share of only ca. 3 per cent of fully transformed products, in 1860s, to 40 per cent in 1914 (Faísca, 2019b: 159).

Thus, the Portuguese cork business had, in the «long» $19^{\text {th }}$ century, a fairly positive evolution. It could have been boosted by state action and/or private economic agents, as it came to be in the $20^{\text {th }}$ century, in problems such as those covered in this article. However, the absence of that impulse did not provide a particular disadvantage in relation to the Spanish cork business. The disadvantage was already there, for historical reasons, when the exploitation of the cork industry appeared in Portugal almost a hundred years after starting in Spain. Despite this gap, the inequality between the two countries was reduced over the $19^{\text {th }}$ century and, some decades later, the situation reversed with the help of State intervention in forestry, industry and commerce of cork products (Zapata Blanco, 2002; Branco, 2005; Parejo Moruno, 2010). 


\section{Bibliography}

ARTIGAS Y TEIXIDOR, Primitivo (1875), El alcornoque y la industria taponera, Madrid, Imp. Manuel Tello.

ARTIGAS Y TEIXIDOR, Primitivo (1888), "Noticia sobre el alcornoque y la industria corchera”, Revista de Montes, 12, 282-291.

ASSOCIAÇÃO PORTUGUESA DE CORTIÇA (2020a), Boletim Estatístico 19/20, Santa Maria da Feira, Associação Portuguesa de Cortiça.

ASSOCIAÇÃO PORTUGUESA DE CORTIÇA (2020b), Montado [online] Available at https://www.apcor. pt/montado/floresta/ [Consult: 2 May 2020].

BRANCO, Amélia (2005), O impacto das florestas no crescimento económico moderno durante o Estado Novo (1930-1974), PhD Thesis, Lisboa, Universidade Técnica de Lisboa.

BRANCO, Amélia, SILVA, Ester Gomes da (2017), "Growth, Institutional Change and Innovation”, in Dulce Freire, Pedro Lains (eds.), An Agrarian History of Portugal, 1000-2000, Leiden, Brill, 219-244.

CABREIRA, Tomás (1914), "A questão corticeira", in Congresso Regional Algarvio, Lisboa, Typ. A Tentadora, 1-16.

CARMO, Miguel (2018), Solo e agricultura no século XX português: um problema ambiental, histórico e epistemológico, PhD Thesis, Lisboa, Universidade de Lisboa.

CASTRO, D. Luiz (1892-1893), "Revista agrícola”, Portugal Agrícola, 1(4), 41-42.

CERÓN, Salvador (1879), Industria forestal-agricola, Cádiz, Biblioteca Nacional Económica.

COSTA, Leonor Freire, MIRANDA, Susana Münch, LAINS, Pedro (2011), História Económica de Portugal, Lisboa, Esfera dos Livros.

EZQUERRA BOTICARIO, Francisco (2009), "Los sistemas de dehesa en la península ibérica: reflexiones acerca de su génesis, historia, dinámica y gestión", in Congreso Forestal Español: Montes y sociedad: Saber qué hacer, Ávila, Sociedad Española de Ciencias Forestales, 1-14.

FAÍSCA, Carlos Manuel (2015), “Criando uma desvantagem? A regulação contratual das práticas suberícolas em Espanha e Portugal (1852-1914)", Revista Portuguesa de História, 46, 413-431.

FAÍSCA, Carlos Manuel (2017), "Promovendo a subericultura? A política florestal de Espanha e Portugal (1852-1914)", Documentos de Trabajo de la Sociedad de Estudios de Historia Agraria, n. 1701.

FAísCA, Carlos Manuel (2019a), "Lagging Behind or Catching Up? The Mechanization of the Portuguese Cork Industry (1880-1914)", Revista de História Industrial, 76(Año XXVIII), 49-77.

FAÍSCA, Carlos Manuel (2019b), El negocio corchero en Alentejo: produción forestal, industria y politica económica, PhD Thesis, Badajoz, Universidad de Extremadura.

FILIPE, Graça, AFONSO, Fátima (coord.) (2010), Quem diz cortiça, diz Mundet, Seixal, Município de Seixal.

FLORES, Alexandre M. (2003), Almada na História da indústria corticeira e do movimento operário: da Regeneração ao Estado Novo (1860-1930), Almada, Câmara Municipal.

GALLEGO FERNÁNDEZ, Juan B., GARCÍA NOVO, Francisco (1997), “Las dehesas de Azuaga (Badajoz): Análisis de cinco siglos de Historia Ecológica", Pastos: Revista de la Sociedad Española para el Estudio de los Pastos, 27(1), 29-46.

GARCÍA GARCÍA, Antonio (2006), Explotación comercial del corcho en la provincia de Badajoz: siglo XIX (Alburquerque y San Vicente de Alcántara), Badajoz, Junta de Extremadura.

GARCÍA GARCÍA, Antonio (2008), Explotación comercial e industrial del corcho en la provincia de Badajoz: Jerez de los Caballeros y Mérida (1833-1912), Badajoz, Editora Regional de Extremadura.

GARCÍA PEREDA, Ignacio (2018), Experts Florestais: Os primeiros silvicultores em Portugal, PhD Thesis, Évora, Universidade de Évora.

GOES, João Maria, TENREIRO, Paulo (2001), A gestão do montado de sobro na charneca de Ponte de Sor, Ponte de Sor, Associação de Produtores Agroflorestais de Ponte de Sor. 
GONÇALVES, Maria de Lurdes Fernandes (2017), Recolha e Análise da informação relativa ao tratamento do fenómeno da desertificação nos PMOT da região do Alentejo, Master's Dissertation, Évora, Universidade de Évora.

LAINS, Pedro (2003), Os progressos do atraso: uma nova história económica de Portugal, 1842 1992, Lisboa, Imprensa de Ciências Sociais.

LEITÃO, Vanda (2004), As primeiras Comissões Geológicas portuguesas (1848-1868), Phd Thesis, Lisboa, Universidade Nova de Lisboa, Faculdade de Ciências e Tecnologia.

LINARES LUJÁN, Antonio (2002), El processo de privatización de los patrimónios de titularidad pública en Extremadura, 1750-1936, Phd Thesis, Barcelona, Universitat de Barcelona.

LINARES LUJÁN, Antonio, ZAPATA BLANCO, Santiago (2003), "Una visión panorámica de ocho siglos", in Fernando Pulido, Pablo Campos, Gregorio Monteiro (eds.), La gestión forestal de las dehesas, Mérida, IPROCOR, 13-28.

MADOZ, Pascual (1847-1850), Diccionario geográfico-estadístico-histórico de España y sus posesiones de Ultramar, Madrid, Vols. VI (1847) e XVI (1850).

MARTINS, Conceição Andrade (2005), "A Agricultura", in Pedro Lains, Álvaro Ferreira da Silva (eds.), História económica de Portugal, Vol. II - O século XIX, Lisboa, Imprensa de Ciências Sociais, 219-259.

NATIVIDADE, Joaquim Vieira (1950), Subericultura, Lisboa, Ministério da Economia.

NATIVIDADE, Joaquim Vieira (1951), A defesa do solo dos sobreirais, Lisboa, Junta Nacional de Cortiça. NUNES, Jacintho (1905), Relatorio sobre a questão corticeira, Lisboa, Typ. A Vapor.

PAREJO MORUNO, Francisco, FAÍSCA, Carlos Manuel, RANGEL PRECIADO, Jose (2013), "Los orígenes de las actividades corcheras en Extremadura: el corcho extremeño entre catalanes e ingleses", Revista de Estudios Extremeños, 69(1), 461-490.

PAREJO MORUNO, Francisco (2010), El negocio del corcho en España durante el siglo XX, Madrid, Banco de España.

PEREIRA, José Campos (1915), A propriedade rústica em Portugal: superfícies, produções, rendimentos, valores, Lisboa, Imprensa Nacional.

PERY, Gerardo (1885), Estatística agrícola do districto de Beja: concelho de Alvito, Lisboa, Imprensa Nacional.

PESSANHA, José Maria (1915), União dos productores de cortiça portugueses: ante-projecto, Cascais, Typ. Cardim.

PICÃO, José da Silva (1947), Através dos campos: usos e costumes agrícolas alentejanos, 2.a ed., Lisboa, Neogravura.

PORTUGAL, Ministério das Obras Públicas, Comércio e Indústria, Direcção-Geral de Agricultura (1894), "Monografia do concelho de Moura", Boletim da Direcção-Geral de Agricultura, 2(VI ano), 212-291.

PULIDO, Fernando, CAMPOS, Pablo, MONTERO, Gregorio (eds.), La gestión forestal de las dehesas, Mérida, IPROCOR.

RADICH, Maria Carlos, ALVES, António Monteiro (2000), Dois séculos de floresta em Portugal, Lisboa, CELPA.

SÁNCHEZ PÁSCUA, Felicidad (1985), Política y educación: incidencias en el Instituto de Segunda Enseñanza de Badajoz (1845-1900), Badajoz, Diputación Provincial de Badajoz.

SERRANO VARGAS, Antonio (2007), El corcho en la sierra norte sevllana: producción, comercialización y transformación industrial en los siglos XIX y XX, PhD Thesis, Sevilla, Universidad de Sevilla.

ZAPATA BLANCO, Santiago (2002), "Del suro a la cortiça. El ascenso de Portugal a primera potencia corchera del mundo", Revista de Historia Industrial, 22, 109-137.

ZAPATA BLANCO, Santiago et al. (dir.) (2012), Jaime Salazar Sampaio: textos de economia corticeira, 1951-1988, Bragança, Instituto Politécnico de Bragança. 